Kontribusi Ulama', oleh: Muslimin

\title{
KONTRIBUSI ULAMA' DALAM PENDIDIKAN ISLAM DARI MASA KE MASA
}

\section{Muslimin*}

\section{Abstrak}

Ulama dalam perspektif pendidikan Islam dapat diartikan sebagai "Professor" (Syaikh), dosen, guru (Mudarris, mu'addib). Peran ulama dalam sistem pendidikan Islam klasik dapat dibedakan menjadi dua yaitu; pertama, peran ulama sebelum berdirinya lembaga Madrasah. Pada periode ini tradisi transmisi keilmuan bersifat individual yaitu ulama merupakan tokoh kunci sebagai pusat keilmuan atau sumber segala ilmu, sehingga tanda kelulusan tidak diberikan oleh lembaga sekolah melainkan oleh person-person individu guru. Dan kedua, peran ulama dalam periode Madrasah. Secara sistematik, pendidikan Islam pada era ini mengalami perubahan baik infra struktur maupun supra struktur. Perubahan mendasar dalam terlihat dalam desain bangunan gedung yang terdiri dari satu kesatuan antara masjid dan ruang kuliah. Sedang peran ulama telah memunculkan kelas ulama tertinggi yakni Syaikh al-Islam serta adanya 'spesialisasi' keilmuan seorang ulama yakni professor bidang hadis, hukum, tasawuf, teologi dan sebagainya.

\section{Kata kunci: Peran Ulama, Pendidikan Islam}

\section{Pendahuluan}

Istilah Ulama' dalam wacana pemikiran kita selama ini sering kami diartikan hanya sebagai orang yang ahli agama, tokoh masyarakat. Atau dalam khasanah sosiologi sering disepadankan dengan predikat sebagai elit masyarakat yang menempati struktur kelas dari agen perubahan masyarakat (Agen of Social Change).

\section{* Institut Agama Islam Tribakti (IAIT) Kediri}


Kontribusi Ulama', oleh: Muslimin

Sebenarnya istilah Ulama' yang demikian ini telah mengalami proses reduksi. Paling tidak ada beberapa makna dari derivasi kata Ulama. Di antaranya adalah seorang yang ahli agama (Scholar of religion). Ahli ilmu figh (Professor of Islamic Law). Seorang iman, ahli sufi, hadist, dan lainnya. ${ }^{1}$ Derivasi peran Ulama semacam ini. Menurut Gilbert, karena sepanjang epoch sejarah Islam, Ulama berperan intensif dan selalu berdialog dalam wacana domain publik. Baik itu wilayah politik, sosial, kebudayaan, dan transformasi intelektual (pendidikan).

Dalam makalah yang singkat ini, penulis hendak mencoba mengelaborasi lebih jauh, bagaimana kiprah Ulama', konstribusi mereka dalam wacana domain transformasi intelektual. Untuk melihat aktivitas Ulama' dalam bidang ini, agar terarah dengan baik, kajian ini berusaha menampilkan serpihan-serpihan data sejarah seputar pendidikan Islam klasik, abad pertengahan (Mediavel age).

Penulis juga sadar, walaupun kajian ini telah dibatasi menurut batasan waktu, kajian ini memang masih menyisakan luasnya area studi. Namun demikian, penulis berusaha untuk menggali data, mencoba menganalisis dan membandingkan, bagaimana peran Ulama' dalam proses transformasi ilmu pengetahuan sebelum terbentuknya lembaga pendidikan tinggi (Madrasah) $^{2}$ dan setelah berdirinya Madrasah itu sendiri.

\section{Sketsa Tentang Asal-Usul Ulama'}

Sebagai catatan pengantar sebelum membahas sumbangan Ulama dalam epoch sejarah pendidikan Islam klasik,

${ }^{1}$ John E. Gilbert, "Institutionalization of Muslim Scholarship and Professionalization of Ulama in Medievel Damascus", dalam Studia Islamica, 52, 1981. 105.

2 Pengertian madrasah sebagaimana penelitian Hasan Asy'ary, tidaklah sama dengan istilah madrasah dalam pengertian kita sehari-hari yang identik dengan pendidikan dasar (sekolah dasar) atau pendidikan menengah (baca: SMU/Madrasah Tsanawiyah/aliyah). Madrasah dalam hal ini sama dengan pendidikan tinggi (college, university, academy). Lebih jelasnya tentang ciri khas madrasah, baca: Hasan Asy'ari, Menyingkap Zaman Keemasan Islam, (Mizan: Bandung, 1991), h. 34. 
Kontribusi Ulama', oleh: Muslimin

ada lebih baiknya dibahas tentang struktur Ulama dalam wacana Islam. Pembahasan ini diharapkan mampu melihat dan membedakan antara peran Ulama' dalam perspektif sosiologis (sebagai agen perubahan sosial, pemimpin ummat, politik, sosial budaya) dan Ulama sebagai dalam perspektif pendidikan. Sebab perlu ditegaskan disini, termasuk Ulama dalam perspektif pendidikan, ia adalah sinonim dari Scholar yang berarti seorang profesional dalam bidang pendidikan. Ulama dapat diartikan sebagai "Professor" (Syaikh), dosen, guru (Mudarris, mu'addib).

Sesungguhnya, wacana Ulama' muncul setelah berakhirnya masa kekhalifahan para sahabat yang empat itu. Gilbert menyebut Ulama' identik dengan Tabi'in. ${ }^{3}$ Dengan demikian, Ulama adalah menandai suatu fase atau periode baru setelah masa pemerintahan empat sahabat Nabi yang dikenal dengan Khulafah al-Rasyidin.

Tepatnya sejak berdrinya dinasti Amawiyah (661-750 M). Ulama' muncul sebagai kelas sosial tersendiri yang bertugas mengaktualisasikan ajaran Islam agar dapat menjadi norma yang masuk dalam setiap sendi kehidupan masyarakat. Munculnya Ulama' sebagai kelas sosial yang mandiri, menurut Syalabi, disebabkan karena sistem pemerintahan dinasti Amawiyah hanya memegang kekuasaan politik an sich. Hal ini berbeda dengan sistem pemerintahan pada masa Nabi atau pun para Sahabat yang empat. Dimana mereka memegang, disamping kekuasaan politik juga kekuasaan agama. ${ }^{4}$ Barangkali dari sini awal mula munculnya istilah Umara' yang berarti birokrat yang memimpin birokratik atau pemerintahan (politik).

Sejak terjadi "pembagian wilayah" antara Umara' dan Ulama' akhirnya lambat laun struktur Ulama' menjadi suatu institusi yang melembaga. Diakui oleh Bulliet, terlihat sekali institusi Ulama' menjadi terlembagakan sedemikian rupa, terutama pada masa dinasti bani Saljuq (1038-1194 M),

3 Gilbert, "Institutionalization of Muslim Scholarship and Professionalization of Ulama in Medievel Damascus", dalam Studia Islamica, 105.

${ }^{4}$ Achmad Syalabi, Tarikh al-Tarbiyah al-Islamiyah, Terj. Muchtar Yahya, (Bulan Bintang: Jakarta, 1975), h. 200-201.

5 Bulliet, R.W, "The Shaykh al-Islam and the Evolution of Islamic Society”, dalam Studia Islamica, 35, 1972, 53. 
Kontribusi Ulama', oleh: Muslimin

bedanya, pada masa dinasti Amawiyah, paran Ulama' sebelum terkontaminasi dalam wilayah politik, sedangkan pada masa dinasti Saljuq kelas Ulama' memang dipersiapkan sedemikian rupa oleh penguasa Saljuq melalui lembaga pendidikan Madrasah. Di samping dinasti Saljuq menginginkan agar mudah mengontrol kelas elit Ulama' dan agar pengaruh mereka yang kuat di masyarakat bisa dimanfaatkan untuk melindungi kepentingan penguasa, mereka juga menjadikan kelas Ulama' sebagai "Perisai" ideologi negara dan simbol otoritas masyarakat Muslim Sunni. Secara tidak langsung otoritas Ulama bagi dinasti Saljuq penting guna melindungi ideologi Sunninya yang menghadapi tantangan yang propagandakan oleh dinasti Fatimiyah (909-1171 M) yang Shi'ah yang didukung oleh korp Ulama'nya.

Sejak Bani Saljuq pula, seperti dikuti Bullet, di samping mendirikan lembaga Madrasah, juga memperkenalkan institutsi baru, Syaikh al-Islam. Melalui lembaga ini, kontrol terhadap ulama' bisa dilakukan lebih efektif, karena lembaga ini adalah sebuah jaringan ulama yang berstruktur secara hirarkis dari ulama di level vertikal sampai ditingkat horizontal. Lembaga ini sekaligus menempatkan ulama' pada posisi strategis sebagai elit politik yang ikut menentukan pengambilan keputusan (dececion makers) pemerintahan. ${ }^{6}$

Pada perkembangan berikutnya, hirarki ulama hampir dapat dijumpai diseluruh dunia Islam sepanjang Afrika Utara, daratan Asia Timur Tengah, hingga Asia Tenggara. Hirarki semacam ini, secara subtansial, peran ulama' tak ubahnya seperti peran dalam konsep kependetaan (priesthood) Kristen, yakni secara sosiologis Ulama memiliki otoritas dalam urusan hukum, moral, teologi, dan pendidikan (agama). ${ }^{7}$

Dari penjelasan di atas, kiranya dapat ditarik kesimpulan bahwa ulama' sebagai kelas sosial memiliki peran yang signifikan, terutama sebagai mediator antara masyarakat dan umara', ulama' secara siginifikan pula, lebih mengetahui karakter masyarakat di bawah. Ia memiliki peran kunci, karena

\footnotetext{
${ }^{6}$ Ibid, 62

${ }^{7}$ George Makdisi, The Rise of College; Institution of Learning in Islam and The West, (Edinburgh: University press, 1981), h.b153.
} 
Kontribusi Ulama', oleh: Muslimin

di luar arena politik, ia paling absah terutama dalam proses transformasi nilai-nilai agama maupun ilmu pengetahuan lainnya. Di sinilah titik singgung peran ulama' dalam wilayah pendidikan yang akan dibahas selanjutnya.

\section{Peran Ulama' dalam Sistem Pendidikan Islam}

Diskursus pendidikan Islam klasik kelihatannya menunjukkan suatu fakta menarik. Bahwa munculnya istilah ulama' dengan berbagai derivasi maknanya puncaknya pada era Madrasah. Paling tidak tulisan Gilbert dan Makdisi menunjukkan tesa ini. Sebagaimana telah sedikit disinggung diawal, bahwa ulama' memiliki derivasi makna yang beragam. Lebih dari itu, dalam karya George Makdisi. The Rice of Colleges. Makdisi lebih mengungkap secara terperinci dari derivasi makna ulama'. Secara umum istilah Mudarris dan Syaikh merujuk pada seorang pengajar ditingkat lembaga pendidikan tinggi. Lebih spesifik, istilah Mudarris jika tanpa embel-embel lain, ia memiliki sinonim sebagai "profesor dalam bidang hukum" (Professor of Law). Sebaliknya istilah Syaikh secara umum biasanya merujuk pada sinonim dari seorang "professor dalam semua bidang ilmu pengetahuan" (Professor of all other fields). ${ }^{8}$ Dengan demikian jika seorang ulama ahli dalam bidang hadist, maka ia adalah seorang professor hadist. Begitu selanjutnya, professor al-Qur'an, Grammatika, Tasawuf, Sufisme, dan seterusnya.

Kelihatannya, spesifikasi dalam setiap bidang baru muncul setelah terbentuknya lembaga pendidikan tinggi Islam (Madrasah). Apakah sebelum era terbentuknya Madrasah belum ada istilah Syaikh atau Professor ? Tentunya hal ini hanya masalah simbol predikat formalitas saja. Dengan kata lain sebelum era Madrasah mengacu pada model klasifikasi Makdisi sudah ada dengan sendirinya. Lebih jauh berikut ini akan dibahas tentang kinerja Ulama' pada abad pertengahan yang

${ }^{8}$ Yang dimaksud masjid-khan di sini adalaah semacam lembaga pendidikan, di samping berdiri bangunan masjid, di sampingnya terdapat bangunan-bangunan yang terdiri dari ruang kuliah dan tempat tinggal para peserta didik, lihat: Menyingkap Zaman Keemasan Islam, 65. 
Kontribusi Ulama', oleh: Muslimin

terbagi antara masa sebelum terbentuknya lembaga Madrasah dan pasca terbentuknya lembaga tersebut.

\section{Peran Ulama Sebelum Berdirinya Lembaga Madrasah}

Jika ditelusuri lebih jauh ke belakang, perhatian kaum muslim terhadap pendidikan dalam pengertian yang seluasluasnya sudah dapat ditemukan pada masa kenabian Muhammad saw. Pendidikan pada masa itu memang terkait erat dengan upaya-upaya penyebaran, penanaman dasar-dasar kepercayaan, dan ibadah Islam. Proses pendidikan yang berlangsung di rumah terkenal dengan sebutan Dar al-Arqam dan bersifat informal itu mengalami perkembangan-perkembangan penting ketika komunitas Islam telah terbentuk. Perkembangan itu dimulai ketika pendidikan mulai diselenggarakan di masjid dalam bentuk halaqah (kelompok-kelompok melingkar) dengan memfokuskan isi pendidikannya pada mata pelajaran membaca, khususnya al-Qur'an, dan menulis. Meskipun demikian, bentuk dan model pendidikan yang diselenggarakan masih bersifat informal.

Dalam konteks teori pendidikan modern, secara umum ciri pendidikan Islam klasik lebih menekankan pada model pendidikan bimbingan dan konseling. Model pendidikan ini menempatkan figur guru sebagai top leader yang selalu mengarahkan dan membimbing serta potensi peserta didik. Ciri ini hampir dapat kita jumpai dalam perjalanan sejarah pendidikan Islam klasik.

Model lembaga pendidikan sebelum era Madrasah yang dimaksud di sini meliputi: al-Kuttab (Pendidikan dasar), Masjid, masjid-khan', halaqoh (kelompok-kelompok melingkar), dan sebagainya. Menurut Fazlur Rahman, selain lembaga al$K h u t t a b$, semua dapat dikategorikan sebagai pendidikan tinggi. ${ }^{10}$

Pada tingkatan pendidikan setelah al-Kuttab, terlihat sekali adanya "reformasi" dan "modernisasi" pendidikan Islam. Masih menurut Rahman, pendidikan al-khuttab hanya menyediakan instrumen pendidikan dasar, yang kurikulumnya

Fazlur Rahman, Islam, Terj. Ahsin Muhammad, (Bandung:

Pustaka, 1984), h. 264

${ }^{10}$ Ibid.

Vol. 23 Nomor. 1 Januari 2012 
Kontribusi Ulama', oleh: Muslimin

meliputi: pendidikan dasar-dasar agama, berhitung yang sederhana, dengan sedikit tambahan membaca dan menulis. Bagi peserta didik yang menginginkan membaca dan menulis dengan baik, perlu bantuan guru yang profesional. ${ }^{11}$ Sama-sama pendidikan dasar, antara pendidikan al-khuttab dan pendidikan yang diadakan untuk istana sudah berbeda. Untuk kategori kedua, muatan kurikulum dan staf pengajar benar-benar telah profesional. Gurunya didatangkan dari kalangan tertentu yang menguasai disiplin ilmu seputar bidang pidato, kesusastraan, nilai-nilai kesatrian, dan tentunya pendidikan agama.

Ada beberapa ciri umum pendidikan Islam pra Madrasah, di antaranya: Pertama, individu-individu guru adalah tokoh-tokoh kunci sebagai pusat informasi keilmuan. Sebaliknya, sekolah-sekolah lembaga formal tidak ikut menentukan polecy umum. Ciri guru sebagai kata kunci (Key Word) adalah ciri utama pendidikan Islam sepanjang periode sebelum berdirinya lembaga Madrasah. Tokoh-tokoh istimewa tertentu, yang telah mempelajari Hadist dan membangun sistemsistem teologi dan hukum mereka sendiri di seputarnya, menarik murid-murid dari daerah-daerah yang jauh dan dekat untuk menimba ilmu. Maka tidak heran, kata Asy'ari, masa lulus pendidikan dan sertifikat (ijazah) pendidikan bukan diberikan oleh lembaga sekolah, melainkan oleh person-person individu guru. ${ }^{12}$

Pada masa ini, telah muncul aliran-aliran teologi yang mandiri. Begitu juga, kodifikasi hukum Islam (Syari'ah) telah mapan pada zaman ini dengan tampilnya nama-nama seperti Malik di Madinah, Abu Hanifah di Irak, juga Imam Al-Syafi'i dan Ahmad bin Hambal.

Tradisi transmisi keilmuan yang bersifat individual memang merupakan bagian tak terpisahkan pada era ini. Lihat saja, Hasan Asy'ari (pencetus teologi Asy'ariyah) juga pernah berguru pada "lawan" teologinya, yakni al-Juba'i sebagai gurunya. Di jaman Islam Klasik ini tidak heran jika seseorang pernah berguru kepada lebih seratus orang guru.

\footnotetext{
${ }^{11}$ Asy'ary, Menyingkap Zaman Keemasan Islam, h. 66

${ }^{12}$ Ibid.
} 
Kontribusi Ulama', oleh: Muslimin

Kedua, walaupun transmisi keilmuan bertolak dari dominasi guru, namun tradisi musyawarah (al-Jidal wa alMujadalah) juga merupakan bagian tak terpisahkan dari ciri khas dinamika pendidikan Islam pada masa ini. Contoh konkrit pola-pola seperti ini pernah dikembangkan oleh Khalifah alMa'mun dan ayahnya. Harun al-Rasyid dari dinasti Abbasyiah. Kedua tokoh ini sering mengadakan debat terbuka, dialog intensif dengan cara mendatangkan para pakar di Istana. Topik pembicaraan juga sangat luas, meliputi: logika, hukum, gramatika, teologi dan filsafat. ${ }^{13}$

Ketiga, muatan kurikulum yang dipelajari juga variatif. Pada masa ini belum nampak munculnya tanda-tanda disiplin ilmu yang dikotomis, antara ilmu agama dan sekuler, atau ilmuilmu Aqliyah dan Naqliyah (meminjam klasifikasi yang dipakai oleh al-Ghazali yang berlaku di masanya dan era sesudahnya). Masa-masa inilah dinamika ilmu pengetahuan mencapai masamasa par excelences. Baith al-Hikmah yang didirikan Khalifah al-Ma'mun melakukan penerjemahan karya-karya Yunani secara besar-besaran. Karya-karya filsafat, matematika, kedokteran, astronomi, seni, sastra, disamping ilmu-ilmu agama berkembang seolah-olah tidak ada batasnya. Apa yang disebut sebagai The Golden Ages terjadi pada masa ini.

Diskripsi di atas memberi fakta bahwa pendidikan Islam pada periode ini secara subtansial telah memenuhi sasaran. Jika dikaji lebih dalam akan ditemukan suatu proses reformasi dan modernisme pendidikan Islam klasik. Seperti diakui Rahman, justru pada masa ini pendidikan Islam berhasil mencetak Ulama'-ulama' besar yang tidak akan pernah ditemui pada periode pendidikan tinggi model Madrasah. ${ }^{14}$ Ilmuan-ilmuan termashur dalam kenyataan sejarah pendidikan Islam lahir dari bekas murid informal dari guru-guru individual.

Periode ini menampakkan sifat pendidikan yang nonformal (subtansial), sementara sifat-sifat formal yang artifisial lebih banyak dikesampingkan, hal ini berbeda dengan sifat sistem pendidikan periode Madrasah akan terlihat selanjutnya.

\footnotetext{
${ }^{13}$ Rahman, Islam, h. 265.

${ }^{14}$ Ibid, h. 269.
} 
Kontribusi Ulama', oleh: Muslimin

\section{Peran Ulama Dalam Periode Madrasah}

Pendidikan formal dalam Islam mulai muncul bersamaan dengan kebangkitan Madrasah. Institusi pendidikan ini lahir pada tahun 1064 diprakarsai oleh Wazir Nizhamiyah di bawah dinasti Nizham al-Mulk dan kemudian terkenal dengan Madrasah Nizham al-Mulk. Kiranya sejak saat itu dan hingga sekarang masih dipergunakan untuk menunjuk institusi-institusi pendidikan Islam secara umum. Menurut Stanton, Madrasah pada masa Islam klasik adalah "the institution of higher learning". ${ }^{15}$ Di samping Madrasah, tradisi pendidikan Islam juga mengenal istilah al-Jami'ah yang secara histories terkait dengan masjid Jami', masjid besar tempat berkumpul dan menunaikan salat jum'at. Universitas al-Azhar, Mesir, merulkan salah satu model universitas-universitas di dunia Islam yang hingga sekarang. Meski pun demikian, baik Madrasah maupun al-Jami'ah tidak serta merta dapat disamakan dengan universitas dalam pengertian universitas litterarum atau universitas magistrorum lembaga pendidikan tinggi yang mengembangkan penyelidikan bebas berdasarkan nalar, karena subtansinya berbeda. Subtansi universitas adalah "penyelidikan bebas berdasarkan nalar" sedangkan Madrasah terutama diabdikan pada al-ulum al-diniyah dengan penekanan khusus pada ilmuilmu tradisional Islam seperti fiqh, tafsir, hadis, dan sebagainya.

Data sejarah tentang pertumbuhan sistem pendidikan era Madrasah banyak ditemui dalam literatur karya semisal Makdisi, Bulliet, Syalabi dan lainnya. Dalam observasinya tentang lembaga pendidikan Islam. Makdisi lebih banyak menggunakan formalitas dari pada fungsionalitas. Begitu juga, pendekatan yang ia pakai lebih banyak menggunakan pendekatan sinkronik dari pada diakronik. ${ }^{16}$ Sehingga kesalahankesalahan dapat saja terjadi.

Secara sistematik, pendidikan Islam pada masa ini memang mengalami banyak perubahan (reformasi). Namun di sisi lain, justru perubahan ini hanya bersifat luarnya saja. Hal ini

15 Charles M. Stanton, Pendidikan Tinggi dalam Islam, Terj. (Jakarta: Logos Publishing House, 1994), h. 54.

16 Stephen R. Humphreys, Islamic History, (London: Princeton University Press, 1995), h. 200. 
Kontribusi Ulama', oleh: Muslimin

akan kita lihat dalam penjelasan nanti, terutama perubahan mendasar dibidang kurikulum yang berdampak besar terhadap kualitas out put.

Madrasah Nizhamiyah dengan berbagai cabang yang tersebar mulai dari Bagdad, Balch, Naisabur, Harat, Isfahan sampai Basrah. ${ }^{17}$ Lembaga ini mencapai puncak perkembangannya pada masa dinasti Ustmani, dipelihara dan ditunjang oleh pejabat "Syaikh Islam" dengan kecakapan dan efisiensi administratif yang tinggi. ${ }^{18}$

Secara mendasar perubahan dalam struktur Madrasah dapat dibagi menjadi dua, infra struktur dan supra struktur. Tidak heran jika Makdisi memberi kesimpulan bahwa model lembaga pendidikan Madrasah dalam Islam menjadi inspirasi bagi penyelenggaraan pendidikan tinggi di Barat modern dewasa ini. ${ }^{19}$ Kesamaan penyelenggaraan model pendidikan Barat dengan Madrasah terlihat dalam beberapa hal; sistem pengorganisasian lembaga, kurikulum, hingga pola-pola pengorganisasian administrasi lembaga.

Perubahan mendasar dalam infra struktur terlihat dalam desain (maket) bangunan gedung. Sebenarnya, desain infra struktur lembaga Madrasah dapat dipahami sebagai evolusi dari pola lembaga Masjid-masjid Khan, akhirnya menjadi lembaga Madrasah. Lembaga Madrasah biasanya terdiri dari satu kesatuan (komplek) dari masjid, ruang kuliah, asrama Mahasiswa, perumahan dosen, ruang laboratorium dan seterusnya. Pola seperti ini pernah ditemukan Syalabi dalam model lembaga Madrasah Al-Nuriyah al-Kubra. ${ }^{20}$ Model bangunan seperti ini tak ubahnya seperti bangunan pendidikan Tinggi di Barat dalam kurun modern dewasa ini.

Lepas dari itu, Madrasah sebagai lembaga pendidikan khas Islam mengalamai perkembangan pesat. Perkembangan itu tidak hanya tampak dalam semakin banyaknya jumlah Madrasah di dunia, tetapi juga tampak dalam modifikasi-modifikasi

17 Syalabi, Tarikh al-Tarbiyah al-Islamiyah, h. 112.

${ }^{18}$ Rahman, Islam, h. 268.

${ }^{19}$ Makdisi, The Rise of College; Institution of Learning in Islam and The West, h. 237 bandingkan: Humphreys, Islamic History, h. 200.

${ }^{20}$ Madrasah ini didirikan oleh Nuruddin Mahmud Zanki Tahun 563 H. Lihat; Syalabi, Tarikh al-Tarbiyah al-Islamiyah, h. 119. 
Kontribusi Ulama', oleh: Muslimin

penyelenggaraan pengajaran sejalan dengan interaksi Islam dengan budaya-budaya lokal. Tak heran jika dalam perkembangannya bahkan hingga masa modern sekarang ini setiap negara muslim memiliki institusi Madrasah. Nama yang dipakai memang tetap madarasah, tetapi isi dan sistem pendidikan yang diterapkan disetiap negara muslim bukan hanya sangat bervariasi, tetapi bahkan dapat dikatakan tidak ada yang sama.

Selanjutnya dalam perspektif perubahan supra struktur dapat dilihat meliputi: bidang administrasi dan kurikulum. Pada perubahan pertama berkaitan erat sekali dengan posisi para Ulama'. Sebagaimana disinggung diawal, sistem Madrasah telah memunculkan kelas Ulama tertinggi, yakni Syaikh al-Islam. Struktur ini lahir dari sistem Madrasah yang berimplikasi luas dalam struktur sosial masyarakat dan politik (pemerintah). Kedua, dalam proses belajar mengajar dalam wacana modern muncul klasifikasi 'guru' secara hirarki itu tersusun mulai tingkat (kepangkatan) seorang Professor (syaikh), asisten professor hingga mudaris (dosen luar biasa). Dalam hirarki ini muncul istilah "spesialisasi" keilmuan; professor di bidang Hadist, Hukum Tasawuf, Teologi, dan sebagainya. Ketiga, disamping hirarki ini juga dikenal jabatan "structural", seperti pegawai administrasi pengurus yayasan, mufti dan sebagainya. Keempat kesejahteraan para guru (pengajar) dijamin dengan didasarkan pada jenjang kepangkatan. ${ }^{21}$

Selanjutnya reformasi dalam bidang kurikulum juga terjadi dalam sistem pendidikan Madrasah. Kurikulum pada masa sistem Madrasah ini lebih ramping dibanding dengan muatan kurikulum pada model pendidikan sebelumnya. Hampir di kebanyakan Madrasah Sunni kurikulum pendidikan lebih banyak didominasi oleh muatan kurikulum agama; yakni Hadist, Hukum, teologi, dan sedikit tasawuf. Sebaliknya Madrasah yang berideologi Syi'ah di samping muatan kurikulum di atas, juga

${ }^{21}$ Dengan panjang lebar Syalabi pernah mengungkapkan gaji-gaji guru yang diterima setiap bulannya. Gaji guru tersebut dapat mencukup kebutuhan hidup mereka lebih dari cukup. Tentang jumlah gaji guru dan perbandingan dengan pegawai dilingkungan pemerintah lainnya. Lihat Syalabi. Tarikh al-Tarbiyah al-Islamiyah, h. 236-239. 
Kontribusi Ulama', oleh: Muslimin

memberi porsi lumayan besar terhadap ilmu-ilmu rasional; filsafat kedokteran, astronomi dan lain sebagainya. Akibatnya, pendidikan Islam masa ini, seperti disimpulkan Rahman, mengalami kelusuhan bahkan kemunduran. ${ }^{22}$ Rahman juga mensinyalir, bahwa kemunduran ini disebabkan karena ditinggalkannya ilmu-ilmu rasional.

Inilah ironi dari pendidikan Islam era Madrasah. Di satu sisi, diakui terjadinya perubahan sistem pada intern lembaga pendidikan Islam (Madrasah), sehingga dengan sistem ini, kinerja Ulama' semakin profesional. Sementara pada sisi lain, perubahan ini membawa dampak negatif bagi mutu kualitas pendidikan Islam, hal ini karena terjadinya pendangkalan dalam muatan kurikulum.

\section{Kesimpulan}

Dari paparan di atas, secara sederhana dapat disimpulkan sebagai berikut. Perkembangan pendidikan Islam klasik yang berkaitan erat dengan kinerja profesionalisme Ulama dapat dipilih menjadi dua fase; fase sebelum berdirinya lembaga pendidikan Madrasah dan Pasca berdirinya lembaga pendidikan Madrasah dan pasca berdirinya Madrasah itu sendiri.

Fase pertama ditandai oleh karakter Ulama sebagai figur sentral yang berperan dalam proses pembentukan keilmuan peserta didik. Fase ini lebih menitik beratkan pada pembaruan pendidikan yang bersifat subtansial tanpa menonjolkan formalitas. Dan kenyataanya telah berhasil melahirkan Ulama'ulama besar. Fase kedua ditandai dengan adanya pembaruan sistem pendidikan secara menyeluruh, yakni meliputi infra struktur dan supra struktur. Pada fase ini, muncullah kelas Ulama' "Profesional".

\section{DAFTAR PUSTAKA}

Bulliet, R.W, "The Shaykh al-Islam and the Evolution of Islamic Society", dalam Studia Islamica, 35, 1972.

22 Fazlur Rahman, Islam dan Modernitas tentang Transformasi Intelektual, (Bandung: Pustaka, 1985), h. 37. 
Kontribusi Ulama', oleh: Muslimin

Gilbert, John E., "Institutionalization of Muslim Scholarship and Professionalization of Ulama in Medievel Damascus", dalam Studia Islamica, 52, 1981.

Humphreys, Stephen R., Islamic History, Princeton University Press: London 1995.

Makdisi, George, The Rise of College; Institution of Learning in Islam and The West, Edinburgh University press, 1981.

Rahman, Fazlur, Islam, Terj. Ahsin Muhammad, Pustaka: Bandung, 1984

Rahman, Fazlur, Islam dan Modernitas tentang Transformasi Intelektual, , Pustaka: Bandung, 1985.

Stanton, Charles M., Pendidikan Tinggi dalam Islam, Terj. Jakarta: Logos Publishing House, 1994.

Syalabi, Achmad, Tarikh al-Tarbiyah al-Islamiyah, Terj. Muchtar Yahya, Bulan Bintang: Jakarta, 1975. 